\title{
PENGARUH TEKNIK PIJAT BAYI TERHADAP KENAIKAN BERAT BADAN \\ BAYI USIA 0-7 BULAN DI BPS NY. AIDA HARTATIK DESA DLANGGU KECAMATAN DEKET KABUPATEN LAMONGAN
}

\author{
Ida Susila* \\ *Dosen Program Studi D III Kebidanan Universitas Islam Lamongan
}

\begin{abstract}
ABSTRAK
Sebenarnya terapi pijat ini dipraktekkan hampir diseluruh dunia termasuk Indonesia. Salah satu terapi pijat yang ditemukan adalah terapi pijat pada bayi. Sensasi sentuh dan raba ini merupakan indera yang aktif berfungsi sejak dini karena bayi telah merasakan sejak masa janin. Secara ilmiah telah dapat dibuktikan bahwa terapi sentuh pada bayi memeng bermanfaat baik secara biokimia maupun fisik. Tujuan penelitian ini adalah mencari pengaruh teknik pijat bayi terhadap kenaikan berat badan. Desain penelitian ini menggunakan metode Pra Eksperimen (One Group Pretest Design).

Metode sampling yang digunakan adalah simple random sampling. Populasi dalam penelitian ini sebanyak 34 bayi. Sample yang diambil 31 bayi.Variabel yang digunakan dalam penelitian ini adalah variabel independent yaitu pijat bayi, sedangkan dependent yaitu kenaikan berat badan bayi. Uji analisis dalam penelitian ini adalah Wilcoxon Sign Rank Test

Hasil penelitian menunjukkan bahwa terdapat pengaruh yang signifikan pijat bayi terhadap kenaikan berat badan bayi dengan signifikasi sebesar 0,000. Dengan hasil t tabel sebesar 0,0 dan $\mathrm{p}$ sebesar 0,000 . Hal ini menunjukkan nilai $\mathrm{p}<0,05$ dan nilai z sebesar $-3,793$ maka $\mathrm{H} 1$ diterima.

Penelitian ini memberikan kesempatan pada peneliti lain untuk melakukan perbandingan lain yang dapat menaikkan berat badan bayi, sehingga dapat ditemukan cara lain yang lebih efektif untuk penanggulangan kenaikan berat badan bayi. Maka diharapkan ibu untuk melakukan pijat bayi.

Kata kunci : Pijat Bayi, Kenaikan Berat Badan Bayi

\section{PENDAHULUAN}

Terapi pijat ini dipraktekkan hampir diseluruh dunia termasuk Indonesia. Salah satu terapi pijat yang ditemukan adalah terapi pijat pada bayi. Terapi pijat ini sekarang masih banyak dilakukan oleh dukun terutama di pedesaan. Menurut

efek bio kimia yang positif dari pijat bayi antara lain, menurunkan kadar hormon stres (catecholamine) dan meningkatkan kadar sterotonin. Sedangkan efek fisik dari pijat antara lain memperbaiki sirkulasi darah dan pernafasan, merangsang fungsi pencernaan dan pembuangan, serta meningkatkan berat badan. (Dede, 2003)
\end{abstract} ketua lembaga peningkatan penggunaan air susu ibu (PP-ASI) RS. Sint Carolus itu, 
Hal ini didukung oleh penelitian yang dilakukan oleh Prof. T. Field \& Scafidi (1986 \& 1990), menunjukna bahwa pada 20 bayi premature dengan berat badan 1280 \& 1176 gram yang dipijat 3 x 15 menit selama 10 hari mengalami kenaikan berat badan per 20 $47 \%$ lebih banyak dari yang tidak dipijat. Penelitian juga dilakukan pada bayi cukup bulan berusia 1-3 bulan yang dipijat selama 15 menit dalam 2 kali seminggu selama 6 minggu, didapatkan kenaikan berat badan yang lebih dari kontrol. (Prof .T.Field \& scafidi,1986). Rene Spitz, dokter anak dan psikiater dari Amerika melaporkan. Bayi yang banyak memperoleh sentuhan khususnya dari ibu, jarang mengalami symptom hipotalasmus. Pengamatan T. Field seperti dikutip di Dr. J. David Hull, ahli Virology Molekuler dari Inggris dalam makalahnya yang berjudul Touch Therapy : Science Confirms Instinct, menyebutkan terapi pijat 30 menit per hari bisa mengurangi depresi dan kecemasan. Tidurpun bertambah tenang dengan pijatan. Dapat juga meningkatkan fungsi motorik dan memperkuat jalinan otot pada bayi yang mengalami down syndrome. Termasuk 44 $\%$ mempengaruhi perbaikan fungsi motorik bayi dan $82 \%$ perbaikan pada otot lengan dan kaki.

Pemijatan yang baik adalah pemijatan yang dilakukan oleh ibu bayi sendiri karena support psikologik dengan jalan kontak psikis dan fisik dari ibu adalah sama besar nilainya dengan lingkungan fisik dan kehangatan ketika bayi masih berada dalam rahim ibu (Kartini Kartono, 2002 : 145). Pemijatan bayi oleh ibunya sendiri dapat dilakukan sejak dini. Bayi baru lahir sebaiknya mengawali tahap pemijatan dengan sentuh karena dapat memberikan jaminan adanya kontak dengan tubuh dan berkelanjutan yang dapat mempertahankan perasaan aman pada bayi. Tetapi kenyataannya di masyarakat terutama di pedesaan masih banyak ibu yang mempercayakan pemijatan bayinya kepada dukun. Salah satu faktor yang mempengaruhi adalah tingkat pengetahuan ibu tentang pemijatan bayi yang benar masih rendah. (Utami Roesli, 2001 : 9).

Pemijatan yang dilakukan oleh dukun pijat yang tingkat pendidikannya rendah dan tidak mengerti dengan benar anatomi fisiologis tubuh manusia, ada kemungkinan terjadi kesalahan dalam pemijatan. Dampak pemijatan yang salah dapat mengakibatkan cacat bahkan kematian. Oleh karena itu pendidikan dan pengetahuan bagi seorang ibu sangatlah penting, maka setiap ibu bayi yang mempunyai bayi perlu mempelajarinya, peran tenaga kesehatan terutama peran bidan sebagai pelaksana sangat dibutuhkan untuk memberikan penyuluhan tentang pemijatan bayi yang benar kepada ibu. Penyuluhan merupakan suatu proses penyampaian, suatu proses atau informasi dari penyuluh kepada sasaran.(Utami Roesli, 2001 : 11).

Berdasarkann survei awal yang dilakukan dari 39 bayi di desa Ndllangu yang mengalami kenaikan berat badan bayi usia 0-7 bulan pada bulan januari 2009 berjumlah 22bayi, 10(45\%) bayi mengalami kenaikan berat badan dan $12(55 \%)$ bayi tidak mengalami kenaikan berat badan.

Dengan demikian petugas kesehatan melakukan teknik pijat bayi dengan tujuan agar berat badan bayi bisa naik, selain itu juga mempunyai dampak 
positif bagi perkembangan fisik dan psikis anak.

Berdasarkan latar belakang diatas, maka masalah dalam penelitian ini adalah pengaruh teknik pijat bayi terhadap kenaikan berat badan bayi usia 0-7 bulan di BPS Ny. Aida Hartatik Desa Ndlanggu Kecamatan Deket Kabupaten Lamongan.

\section{TUJUAN PENELITIAN}

Untuk mengetahui pengaruh teknik pijat bayi terhadap kenaikan berat badan bayi usia 0-7 bulan di BPS Ny. Aida Hartatik Desa Ndlanggu Kecamatan Deket Kabupaten Lamongan.

\section{TINJAUAN PUSTAKA}

Pijatan adalah komunikasi pada tingkat terdalam, tanpa bataasan kata-kata merupakan pesan yang mengandung kehangatan dari cinta bagi bayi (Turne Roma, 2001 : 16), pijat adalah terapi sentuh (Utami Roesli, 2001 : 2). Pijatan adalah sentuhan yang ringan dan langsung atau keras dan lembut, gabungan luas dan lembut ( Harmoni, 2002 : 4). Pijat merupakan salah satu bentuk dari terapi sentuh yang berfungsi sebagai salah satu teknik pengobatan penting (Kalbe Health Foods, $2001:$ 12).

\section{Manfaat Pemijatan}

Meningkatkan berat badan

Penelitian yang dilakukan oleh T. Field dan Scafidi (1986 dan 1990), pada bayi cukup bulan yang berusia 1-3 bulan, yang dipijat 12 menit, 2 kali seminggu selama 6 minggu didapatkan kenaikan berat badan yang lebih dari bayi kontrol. Antara lain : meningkatkan pertumbuhan, meningkatkan konsentrasi bayi dan membuat bayi tidur lebih lelap, meningkatkan daya tahan tubuh, ini akan menyebabkan terjadinya penurunan kadar hormon adrenalin (hormon stres) penurunan pada hormon stres ini akan meningkatkan daya tahan tubuh, terutama IgM dan $\operatorname{IgG}$.

Pijatan dapat mengubah gelombang otak, pijat bayi akan membuat bayi tidur lebih lelap dan meningkatkan kesiagaan (alertness) atau konsentrasi. Hal ini disebabkan pijatan gelombang otak, perubahan ini terjadi dengan cara menurunkan gelombang alpha dan meningkatkan gelombang beta serta teta, yang dapat dibuktikan dengan menggunakan electro encephalogram (EEG), antara lain : Membina ikatan kasih sayang orang tua dan anak (Bonding), Mengendalikan temperamennya, Meningkatkan produksi ASI.

Pada penelitian Cintia Mersmann, ibu-ibu yang bayinya dipijat secara rutin ternyata dapat memproduksi ASI perah lebih banyak dibanding kelompok kontrol jadi, dengan meningkatkan volume ASI perah, pijat bayi juga dapat meningkatkan periode waktu pemberian ASI secara eksklusif oleh ibu-ibu yang bekerja : Memacu sistem sirkulasi bayi dan denyut jantung, pernafasan, pencernaan dan sistem kekebalan tubuh. Mendorong pertumbuhan susunan otot dan kelenturan dimana akan membantu dalam pertumbuhan kemampuan fisik bayi.

Petunjuk Memijatan Bayi. 
Pijat bayi dapat segera dimulai setelah bayi dilahirkan sesuai dengan keinginan orang tua. Dengan lebih cepat mengawali pemijatan, bayi akan mendapat keuntungan yang lebih besar. Apalagi jika pemijatan dapat dilakukan setiap hari, dari sejak kelahiran sampai bayi berusia $6-7$ bulan (Utami, 2001).

Waktu terbaik memijat bayi

1. Pagi hari, pada saat orang tua dan anak siap untuk memulai hari baru

2. Malam hari, sebelum tidur, ini sangat baik untuk membantu bayi tidur lebih nyenyak

3. Antara 2 waktu makan saat bayi tidak terlalu kenyang namun juga tidak terlalu lapar

Persiapan alat :

1. Kain tebal untuk alas bayi/selimut bayi

2. Handuk

3. Mangkuk kecil untuk tempat baby oil

4. Baby oil

5. Bila bayi terbiasa diberi susu botol, pastikan susu sudah siapkan sebelumnya

6. Baskom isi air hangat untuk memandikan bayi setelah pemijatan terakhir

7. Baju ganti bayi

8. Bila ada tape atau radio yang terdapat lagu-lagu yang tenang

Cara pemijatan sesuai umur bayi :

1. $0-1$ bulan, disarankan gerakan yang lebih mendekati usapan - usapan halus. Sebelum tali pusat bayi lepas sebaiknya tidak dilakukan pemijatan di daerah perut.

2. $1-3$ bulan, disarankan gerakan halus disertai dengan tekanan ringan dalam waktu yang singkat.

3. 3 bulan sampai 3 tahun, disarankan seluruh gerakan dilakukan dengan tekanan dan waktu yang semakin meningkat.

\section{HIPOTESIS PENELITIAN}

Hipotesis adalah jawaban sementara terhadap masalah yang diajukan yang kebenaranya akan dibuktikan dengan penelitian yang akan dilakukan.

Uji hipotesis dalam penelitian ini adalah ada pengaruh pijat bayi terhadap kenaikan berat badan bayi usia 1-7 bulan di BPS Aida Hartatik, Amd. Keb Desa Ndlanggu Kecamatan Deket Kabupaten Lamongan pada bulan Januari - Maret 2010 .

\section{METODE PENELITIAN}

Desain penelitian yang digunakan adalah Pra-Eksperimental (One Group Pratest Posttest Design) yaitu kelompok subyek diobservasi sebelum dilakukan intervensi kemudian diobservasi lagi setelah intervensi (Nursalam, 2003:88).

Sampel yang digunakan dalam penelitian ini adalah sebagian ibu yang mempunyai bayi yang berusia 1-7 bulan di BPS Ny.Aida Hartatik desa Ndlanggu Kecamatan Deket Kabupaten Lamongan yang memenuhi kriteria inklusi.

\section{HASIL PENELITIAN}

Table 5.1 Frekuensi Responden berdasarkan umur di BPS Ny. Aida Hartatik Amd, Keb. Desa Ndlanggu Kecamatan Deket Kabupaten Lamongan bulan Januari sampai Maret tahun 2016

\begin{tabular}{|c|c|c|c|}
\hline No & Umur & Jumlah & $\begin{array}{c}\text { Persentase } \\
(\boldsymbol{\%})\end{array}$ \\
\hline 1 & 1 bulan & 4 & 12,9 \\
\hline
\end{tabular}




\begin{tabular}{|c|c|c|c|}
2 & 2 bulan & 4 & 12,9 \\
3 & 3 bulan & 5 & 16,1 \\
4 & 4 bulan & 5 & 16,1 \\
5 & 5 bulan & 7 & 22,6 \\
6 & 6 bulan & 4 & 12,9 \\
7 & 7 bulan & 2 & 6,5 \\
\hline \multicolumn{2}{|c}{ Total } & 31 & 100 \\
\hline
\end{tabular}

Berdasarkan data di atas menunjukkan hampir sebagian besar responden berumur 5 bulan yaitu sebanyak 7 bayi $(22,6 \%)$ dan hanya sebagian kecil yang berumur 7 bulan yaitu sebanyak 2 bayi $(6,5 \%)$.

\subsubsection{Data Khusus}

1). Hasil analisis mengenai pijat bayi terhadap kenaikan berat badan bayi usia 17 bulan

Tabel 5.2 Distribusi berat badan bayi usia 1-7 bulan sebelum dilakukan pijat bayi

\begin{tabular}{|c|c|c|c|c|}
\hline No & Umur & $\begin{array}{c}\text { BB } \\
\text { sebelum } \\
\text { di pijat }\end{array}$ & $\begin{array}{c}\text { Jum } \\
\text { lah }\end{array}$ & $\begin{array}{c}\text { Persentas } \\
\mathbf{e}(\%)\end{array}$ \\
2 & $\begin{array}{c}1 \\
\text { bulan }\end{array}$ & $3-3,3$ & 4 & 12,9 \\
3 & $\begin{array}{c}2 \\
\text { bulan } \\
\text { bulan }\end{array}$ & $4,2-4,5$ & 5 & 12,9 \\
4 & 4 & $4,9-5$ & 5 & 16,1
\end{tabular}

\begin{tabular}{|c|c|c|c|c|} 
& bulan & & \\
5 & 5 \\
6 & $5,5-6,2$ & 7 & 22,6 \\
& 6 & $5,9-6,1$ & 4 & 12,9 \\
7 & $\begin{array}{c}\text { bulan } \\
7\end{array}$ & $7,2-7,4$ & 2 & 6,5 \\
& bulan & & & \\
\hline \multicolumn{2}{|c|}{ Total } & & 31 & 100 \\
\hline
\end{tabular}

Berdasarkan data dari tabel 5.2 di atas dari 31 responden menunjukkan yang paling banyak bayi berumur 5 bulan yaitu sebanyak 7 bayi $(22,6 \%)$ dan yang paling sedikit bayi berumur 7 bulan yaitu sebanyak 2 bayi $(6,5 \%)$.

2). Hasil analisis mengenai pijat bayi terhadap kenaikan berat badan bayi usia 17 bulan

Tabel 5.3 Distribusi berat badan bayi usia 1-7 bulan setelah dilakukan pijat bayi

\begin{tabular}{|c|c|c|c|c|c|c|}
\hline No & Umur & $\begin{array}{l}\text { Berat } \\
\text { Badan }\end{array}$ & \multicolumn{2}{|l|}{$\begin{array}{l}\text { Setelah } \\
\text { dipijat } \\
\text { naik }\end{array}$} & \multicolumn{2}{|c|}{$\begin{array}{c}\text { Setelah } \\
\text { dipijat } \\
\text { tetap }\end{array}$} \\
\cline { 3 - 7 } & & Jml & $(\%)$ & Jml & $(\%)$ \\
\hline 1 & $\begin{array}{c}1 \\
\text { bulan }\end{array}$ & $\begin{array}{c}2,8- \\
4,5\end{array}$ & 3 & 9,67 & 1 & 3,2 \\
2 & $3,8-$ & 3 & 9,67 & 1 & 3,2 \\
3 & $\begin{array}{c}3 \\
\text { bulan } \\
\text { bulan }\end{array}$ & $\begin{array}{c}3,7 \\
3\end{array}$ & 2 & 6,5 & 3 & 9,67 \\
\hline
\end{tabular}




\begin{tabular}{|c|c|c|c|c|c|c|}
\hline 4 & $\begin{array}{c}4 \\
\text { bulan }\end{array}$ & $\begin{array}{c}4,7- \\
5,7\end{array}$ & 3 & 9,67 & 2 & 6,5 \\
\hline 5 & $\begin{array}{c}5 \\
\text { bulan }\end{array}$ & $\begin{array}{c}5,7- \\
6,6\end{array}$ & 5 & 16,1 & 2 & 6,5 \\
\hline 6 & $\begin{array}{c}6 \\
\text { bulan }\end{array}$ & $\begin{array}{c}6,4- \\
6,8\end{array}$ & 4 & 12,9 & 0 & 0 \\
\hline 7 & $\begin{array}{l}7 \\
\text { bulan }\end{array}$ & $\begin{array}{c}7,1- \\
7,9\end{array}$ & 1 & 3.2 & 1 & 3,2 \\
\hline \multicolumn{3}{|c|}{ Total } & 21 & $\begin{array}{c}67,7 \\
1\end{array}$ & 10 & $\begin{array}{c}32,7 \\
7\end{array}$ \\
\hline
\end{tabular}

Berdasarkan data dari tabel 5.3 di atas dari 31 responden menunjukkan yang paling banyak bayi mengalami kenaikan berat badan berumur 5 bulan yaitu sebanyak 5 bayi $(16,1 \%)$ dan yang paling sedikit bayi berumur 7 bulan yaitu sebanyak 1 bayi $(3,2 \%)$

3). Pengaruh pijat bayi terhadap kenaikan berat badan bayi usia 1-7 bulan Hasil analisis mengenai pengaruh pijat bayi terhadap kenaikan berat badan bayi usia 1-7 bulan, dapat dilihat pada tabel 5.4 dibawah ini :

Tabel 5.4 Analisis pengaruh pijat bayi terhadap kenaikan berat badan bayi usia 1-7 bulan di BPS Ny. Aida Hartatik Amd.Keb Desa Ndlanggu Kecamatan Deket Kabupaten Lamongan Bulan Januari -Maret Tahun 2016

\begin{tabular}{|l|c|c|c|c|}
\hline VARIABEL & $\mathrm{Z}$ & $\mathrm{P}$ & MEAN & $\mathrm{T}$ \\
\hline SEBELUM & - & 0,000 & 21,00 & 0,0 \\
DIPIJAT- & 3,793 & & & \\
SETELAH & & & & \\
DIPIJAT & & & & \\
\hline
\end{tabular}

Berdasarkan Tabel 5.4 yang merupakan hasil analisis statistik Wilcoxon, didapatkan hasil nilai t tabel sebesar 0,0 dengan p sebesar 0,000. Hal ini menunjukkan nilai $\mathrm{p}<0,05$ dan nilai $\mathrm{z}$ sebesar -3,793 maka $\mathrm{H} 1$ diterima dalam arti terdapat pengaruh pijat bayi terhadap kenaikan berat badan bayi usia 1-7 bulan.

\section{PEMBAHASAN \\ Berat Badan Bayi}

Dari tabel 5.2 di atas dari 31 responden menunjukkan yang paling banyak bayi berumur 5 bulan yaitu sebanyak 7 bayi $(22,6 \%)$ dan yang paling sedikit bayi berumur 7 bulan yaitu sebanyak 2 bayi $(6,5 \%)$.

Menurut Soetjiningsih kebutuhan dasar anak terbagi atas kebutuhan fisikbiomedis (asuh), kebutuhan emosi/kasih sayang (asih) dan kebutuhan akan stimulasi mental (asah). Kebutuhan fisik meliputi pangan/gizi yang merupakan kebutuhan terpenting. Kebutuhan dasar anak kedua adalah kebutuhan emosi/kasih sayang. Pada tahun-tahun pertama kehidupan hubungan yang erat, mesra dan selaras antara ibu dengan anak merupakan syarat mutlak untuk menjamin tumbuh kembang anak baik fisik, mental maupun psikososial.

Peningkatan berat badan bayi ini disebabkan oleh terjadi karena bayi yang dipijat mengalami peningkatan tonus nervus vagus (saraf otak ke-10) yang membuat kadar enzim penyerapan gastrin dan insulin meningkat sehingga penyerapan sari makanan menjadi lebih baik. 
Berat badan merupakan hasil peningkatan atau penutupan semua jaringan yang ada pada tubuh lain : tulang, otot, caiaran tubuh dan yang lainnya (Soetjiningsih, 2005 :38). Pertumbuhan dan perkembangan merupakan proses yang terjadi pada makhluk hidup. Pertumbuhan dan perkembangan menyangkut semua aspek semua kemajuan yang dicapai sejak dalam kandungan hingga dewasa.

Pertumbuhan adalah bertambahnya ukuran fisik dan stuktur tubuh dalam arti sebagian atau seluruhnya karena adanya multiplikasi (bertambah banyak) sel-sel tubuh dan juga karena bertambah besarnya sel. Adanya multiplikasi dan pertambahan ukuran sel berarti ada pertambahan secara kuantitatif dan hal tersebut terjadi sejak terjadinya konsepsi, yaitu bertemunya sel telur dan sperma hingga dewasa. Jadi pertumbuhan lebih ditekankan pada pertambahan ukuran fisik seseorang, yaitu menjadi lebih besar atau lebih matang bentuknya, seperti pertambahan ukuran berat badan, tinggi badan, dan lingkar kepala (IDAI, 2002).

Kenaikan berat badan anak pada tahun pertama kehidupan, apabila anak mendapat gizi yang baik, menurut Wong, D.L.(2003) adalah berkisar antara:

1. Bayi lahir-6 bulan : pertambahan setiap minggu 140-200 gram. Berat badan lahir dua kpada akhir 6 bulan pertama.

2. 6-12 bulan : pertambahan setiap minggu 85-400 gram. Berat badan tiga kali berat badan lahir pada akhir tahun pertama.

Pengamatan T. Field yang dikutip dr. J. David Hull, ahli virologi mulekuler dari Inggris, dalam makalah berjudul Touch Therapy: Science Confirms Instinct, menyebutkan terapi pijat 30 menit per hari bisa mengurangi depresi dan kecemasan pada bayi sehingga bayi dapat tidur lebih nyeyak dan tenang. Terapi pijat yang dilakukan 15 menit selama enam minggu pada bayi usia 1-3 bulan juga meningkatkan kesiagaan. Diikuti dengan peningkatan berat badan, perbaikan kondisi psikis, berkurangnya kadar hormone stres, dan bertambahnya kadar serotonin. Meningkatnya aktivitas neurotransmitter serotonin ini akan meningkatkan kapasitas sel reseptor yang mengikat glucocorticoid (adrenalin). Proses ini menyebabkan terjadinya penurunan kadar hormone adrenalin (hormone stres), dan selanjutnya akan meningkatkan daya tahan tubuh.

Berdasarkan hasil penelitian dan teori, maka tidak didapatkan kesenjangan antara hasil penelitian dan teori karena dari 31 responden banyak yang berat badannya naik 21 bayi $(67,7 \%)$, dan berat badannya tetap 10 bayi $(32,3 \%)$. Faktor - faktor yang dapat mempengaruhi yaitu umur, keluarga, jenis kelamin. Salah satu cara yang dapat dilakukan oleh orang tua untuk mengoptimalkan pertumbuhan masa bayi adalah dengan memenuhi kebutuhan dasar dalam tumbuh kembang seperti yang telah disebutkan diatas, serta pentingnya untuk melakukan stimulasi tumbuh kembang yang lebih awal pada bayi, salah satu contoh stimulasi adalah dengan melakukan pijat bayi.karena pijat bayi dapat meningkatkan produksi ASI dan merangsang peningkatan nafsu makan sehingga dapat meningkatkan berat badan bayi secara optimal. Banyak cara mengatasi masalah ini, salah satu cara yang dengan menggunakan pijat bayi. Cara ini diharapkan mampu menaikkan berat badan bayi. 


\section{Pengaruh pijat bayi terhadap kenaikan berat badan bayi usia 1-7 bulan}

Uji statistic Wilcoxon Sign Rank Test menunjukkan nilai $\mathrm{p}$ sign $<0,05$ dan $\mathrm{Z}$ hitung $>\mathrm{Z}$ tabel sehingga terdapat pengaruh pijat bayi terhadap kenaikan berat badan bayi usia 1-7 bulan.

Berat badan merupakan hasil peningkatan atau penutupan semua jaringan yang ada pada tubuh lain : tulang, otot, caiaran tubuh dan yang lainnya (Soetjiningsih, 2005 :38). Pertumbuhan dan perkembangan merupakan proses yang terjadi pada makhluk hidup. Pertumbuhan dan perkembangan menyangkut semua aspek semua kemajuan yang dicapai sejak dalam kandungan hingga dewasa.

Pertumbuhan adalah bertambanya ukuran fisik dan stuktur tubuh dalam arti sebagian atau seluruhnya karena adanya multiplikasi (bertambah banyak) sel-sel tubuh dan juga karena bertambah besarnya sel. Adanya multiplikasi dan pertambahan ukuran sel berarti ada pertambahan secara kuantitatif dan hal tersebut terjadi sejak terjadinya konsepsi, yaitu bertemunya sel telur dan sperma hingga dewasa. Jadi pertumbuhan lebih ditekankan pada pertambahan ukuran fisik seseorang, yaitu menjadi lebih besar atau lebih matang bentuknya, seperti pertambahan ukuran berat badan, tinggi badan, dan lingkar kepala (IDAI,2002).

Sebenarnya terapi pijat ini dipraktekkan hampir diseluruh dunia termasuk Indonesia. Salah satu terapi pijat yang ditemukan adalah terapi pijat pada bayi. Terapi pijat ini sekarang masih banyak dilakukan oleh dukun terutama di pedesaan. Menurut ketua lembaga peningkatan penggunaan air susu ibu ( PP-
ASI) RS. Sint carolus itu, efek bio kimia yang positif dari pijat bayi antara lain, menurunkan kadar hormon stres (catecholamine) dan meningkatkan kadar sterotonin. Sedangkan efek fisik dari pijat antara lain memperbaiki sirkulasi darah dan pernafasan, merangsang fungsi pencernaan dan pembuangan, serta meningkatkan berat badan. (Dede, 2003)

Hal ini didukung oleh penelitian yang dilakukan oleh Prof. T. Field \& Scafidi (1986 \& 1990), menunjukna bahwa pada 20 bayi premature dengan berat badan 1280 \& 1176 gram yang dipijat 3 x 15 menit selama 10 hari mengalami kenaikan berat badan per 20 $47 \%$ lebih banyak dari yang tidak dipijat. Penelitian juga dilakukan pada bayi cukup bulan berusia 1-3 bulan yang dipijat selama 15 menit dalam 2 kali seminggu selama 6 minggu, didapatkan kenaikan berat badan yang lebih dari kontrol. (Prof .T. Field \& Scafidi,1986).

Berdasarkan penelitian yang dilakukan di BPS Ny.Aida Hartatik Desa Ndlanggu Kecamatan Deket Kabupaten Lamongan pada bayi yang mengalami kenaikan berat badan setelah diberi pijat bayi sebagian besar mengalami naiknya berat badan. Hal ini di sebabkan karena efek fisik dari pijat antara lain memperbaiki sirkulasi darah dan pernafasan, merangsang fungsi pencernaan dan pembuangan, serta meningkatkan berat badan.

Banyak cara mengatasi masalah kenaikan berat badan, salah satu cara yaitu dengan teknik pijat bayi. Pemberian teknik pijat bayi yaitu adalah terapi sentuh. Pijatan adalah sentuhan yang ringan dan langsung atau keras dan lembut, gabungan luas dan lembut ( Harmoni, 2002 : 4). Pijat 
merupakan salah satu bentuk dari terapi sentuh yang berfungsi sebagai salah satu teknik pengobatan penting.

\section{KESIMPULAN}

1. Sebagian besar responden mengalami kenaikan berat badan setelah dilakukan pijat bayi.

2. Sebagian kecil responden mengalami tetapnya berat badan setelah di lakukan pijat bayi.

3. Ada pengaruh pijat bayi terhadap kenaikan berat badan bayi usia 1-7 bulan di desa ndlangu kecamatan deket kabupaten lamongan, hal ini di dasarkan pada uji statistik Wilcoxon Sign Rank Test dengan menggunakan SPSS versi 16.

\section{SARAN}

Bagi Responden diharapkan dalam mengatasi kenaikan berat badan bayi lebih baik di lakukan pijat bayi yang dalam pemberian pijat bayi perlu diperhatikan dengan benar.

Bagi Tenaga kesehatan diharapkan tenaga kesehatan khususnya bidan untuk lebih meningkatkan tentang pemijatan bayi yang benar dan memberikan penyuluhan pada para ibu untuk melakukan pemijatan bayi secara rutin.

Bagi Profesi Kebidanan diharapkan dalam profesi kebidanan dapat mempertimbangkan untuk menerapkan pijat bayi untuk mengatasi kenaikan berat badan. Karena hasil penelitian ini terdapat pengaruh teknik pijat bayi terhadap kenaikan berat badan bayi

\section{DAFTAR PUSTAKA}

Aritonang. (2001). Pertumbuhan berat badan bayi usia 0-6 bulan : Jakarta.

Cholid Narbuko dan Abu Achmadi. (2001). Metodelogi Penelitian. Jakarta : Bumi Aksara.

Dede. (2003). Konsep Pijat Bayi. Jakarta (http://www.healthytoday.net), Minggu, 20 Desember 2009.

Harmoni, 2002, Terapi Turnia. Tim harmoni; Jakarta (http://www.esilaturahim .com), Sabtu, 2 Januari 2010.

Kalbe, Farma. 2001. Cara Yang Baik Merawat Si Kecil. Jakarta: PT. SANGHIANG PERKASA.

Kartono, Kartini, 2002. Patologi Social 3. CV Rajawali ; Jakarta.

Nursalam. @ Siti Pariani. (2001). Pendekatan Praktis Metodologi Riset Keperawatan. CV. SAGUNG SETO : Jakarta.

Nursalam. (2003). Konsep dan Penerapan Metodologi Penelitian IImu Keperewatan Pedoman Skripsi, Tesis dan Instrumen Penelitian Keperawatan. Jakarta : Salemba Medika.

Roesli, Utami.2001. Pedoman Pijat Bayi Prematur. Trubus Agri Widya : Jakarta.

Roesli, Utami. 2001. Pedoman Pijat Bayi . Trubus Agri Widya : Jakarta. 
Roma, Turne, 2001. Seni Memijat Yang Menyejukan. Ladang Pustaka : Jakarta.

Soetjiningsih. (2005). Konsep Pertumbuhan Berat Badan : Jakarta.
Sugiono. (2006). Statistika untuk Penelitian. Bandung : Alfabeta.

Supriasa. (2005). Penentuan Berat Badan Dengan Cara Menimbang : Jakarta.

Wong, D.L. (2003). Kenaikan Berat Badan Anak : Jakarta. 